\title{
CORRESPONDENCE
}

\author{
MAGMA TYPES
}

SrR,-The recent paper by Mr. M. K. Wells and Dr. A. K. Wells on Magma Types (Geol. Mag., 1948, p. 349), and the letter thereon by Professor A. Holmes (Geol. Mag., 1949, p. 71), have caused me to consult my own use of the term. This occurs in my paper "On the Basaltic Lavas penetrated by the Deep Boring for Coal at Bhusawal, Bombay Presidency ", Rec. Geol. Surv. Ind., liii, p. 196 (1925). This paper was written in Calcutta during the recess period of 1924 , so that my use of the term "magma-type "was made in ignorance of its use by the authors of the Mull memoir published in the same year, to which, consequently, I make no reference.

As a result $I$ find that $I$ have used the term with a significance somewhat different from that of the Mull memoir. My paper contains a record, with description of the mineralogy and petrology, of 1,171 feet vertical of horizontal basaltic lavas of the Deccan Trap formation pierced in a deep bore-hole for coal. The study of the cores showed that twenty-nine flows had been cut, and that the range of thickness of the twenty-seven flows completely pierced was from 5 feet to $97 \mathrm{ft} .3 \mathrm{in}$., with an average thickness of $40 \mathrm{feet}$. No analyses were made of these rocks, but from the microscope study, making use of mineralogical and other peculiarities, it was possible to arrange them into seven groups based on the absence or presence of phenocrysts of olivine and labradorite, and on whether these had remained suspended in the flow or had sunk towards the base. These seven groups were made into two types according to peculiarities exhibited by the iron-ores; and it was these two more comprehensive groups that were designated magma-types, on the hypothesis that they had come from different magma-sources.

Sub-crustal and intercrustal magma-basins are discussed on the assumption that these basaltic rocks had come as liquids from subterranean sources, often carrying in suspension phenocrysts of labradorite and olivine of intratelluric origin. The evidence was held to show that the difference between the porphyritic basalts with phenocrysts of labradorite and olivine and nonporphyritic basalts was entirely due to gravitative settling within a magmareservoir, and I did not find any evidence for the hypothesis that the olivinic and non-olivinic basalts came from different ultimate sources. My two magma-types each include porphyritic and non-porphyritic basalts. It may be that chemical analysis would show that these two types have no widereaching special significance. I do not see why they should, as I attribute all these Deccan Trap effusions to the same ultimate source, namely my infraplutonic eclogite shell.

Professor Holmes may already know the answer to the question whether there is any significant difference chemically between my two magma-types, since many years ago he asked for, and was I believe supplied with, specimens of my Bhusawal basalts for purposes of chemical study.

$$
\text { Yours faithfully, }
$$

24 Durdham Park,

L. L. FERMOR.

\author{
BRISTOL, 6. \\ 2nd July, 1949.
}

\section{EAST ANGLIAN DRIFTS}

SIR,-It is distinctly hard on Mr. Baden-Powell that the evidence which led to my East Anglian views should have been produced, and illustrated, in London so soon after his letter was written. For that reason it would be unfair to take his attitude as final, and futile to start a discussion until that evidence, notably as to Corton and Hoxne, is published and can be assessed.

In the meantime may I make a general comment, addressed not so much 
to Mr. Baden-Powell, as to all those who oppose this Undermelt Theory and the conclusions arising therefrom. Since the gage has been thrown, their task is to defend the orthodox view that here in Northern England we had a series of ice advances and retreats, the latter marked by extraglacial sedimentations which may or may not be of Interglacial rank, but do at any rate indicate periods of deglaciation. What they have to show, therefore, is that all the peculiarities of the laminated clays, silts, and sands within the drifts of that area can be matched in unquestioned lacustrine, estuarine, or marine deposits which are preferably, though not necessarily, built up from the erosion of Glacial detritus : all is the operative word, please. But that is not the end, for they then have to account for the till-on-sand contacts and "roof-falls", as I call them, harmonizing them with forward ice-movements. If they would wait until the new evidence of which $I$ have spoken is published, they would then have all the data before them, and could go ahead secure in the knowledge that no further mines are to be sprung in their path.

In this matter, I do not take my stand on being partly right, but on being wholly right. There was in Britain but one great glaciation - the Saale, or Mindel of the Alps: the rest were but small mountain affairs. Rarely in geology has there been an issue so clear-cut as this. In truth, there is no room here for that compromise so dear to the British mind, or even for that which is so dear to the professional mind, the making of a simple thing complicated. And the curious-minded will find a commentary on the situation as a whole on page 198 of W. B. Wright's Quaternary Ice-Age; the first edition, not the second. Subject apart, what he had to say serves to admiration our present business.

HIGH BARN,

R. G. Carruthers.

STOCKSFIELD ON TYNE.

20th July, 1949.

\section{REVIEWS}

Geology of the Northern Pennine Orefield. Volume 1. Tyne to Stainmore. By K. C. Dunham. Memoir Geological Survey of Great Britain, pp. 357, with 33 text-figures and 4 folding plates. 1948. Price 17s. 6d.

This admirable volume is based on a war-time reinvestigation of the mineral deposits of the Northern Pennines by an author pre-eminently fitted for the task. It deals mainly with the area of Carboniferous rocks extending southwards from the Tyne valley to the Stainmore gap, between Barnard Castle and Brough, a region once famous for its lead mining and still an active producer of barytes, witherite, and fluorspar.

A brief outline of the history of mining is followed by a lucid account of the stratigraphical succession, with its remarkable repetitions of rhythmic series, or cyclothems, in the Middle Limestone Group of the Carboniferous Limestone Series, and by a short description of the igneous intrusions, notably the Whin Sill and related dykes. The gentle asymmetric dome structure of the Alston Block is well illustrated by a map which not only shows contours on the base of the Great Limestone, but also displays the perfect conjugate pattern of the vein-fissures throughout the orefield. These fissures, associated with normal faulting, typically steepen and widen out in the harder beds, and since the tearing-apart of their walls is probably due to tension resulting from domal uplift, it unfortunately follows that the width of openings propitious for ore deposition must diminish as the veins are followed in depth - an inference borne out by past mining operations. Owing to their physical response to fracturing, the hard limestones, dolerite,

VOL. LXXXVI. NO. 5 . 